\title{
ENERGY ENGINEERING - A SYLLABUS FOR THE 21ST CENTURY
}

\section{Jaroslav ŠÍPAL}

\begin{abstract}
Energy Engineering has again become an attractive field. Students are attracted by the employment prospects fueled by the shortage of qualified professionals as well as future challenges in the field such as electric vehicles, smart grids, new sources of energy etc. This impacts the requirements on the curriculum of the Energy Engineering programs, because students must be provided with a skill set that will enable them to remain competitive even in distant future of 30-40 years when energy engineering will have completely changed, whilst they still must be ready to face the challenges of today. This paper discusses these issues and shows how a new program at the Jan Evangelista Purkyne University in Usti nad Labem, Czech Republic, attempts to address them. The successful increase in applicants and students over the last three years is seen as evidence that the program meets the expectations of both students and industry.
\end{abstract}

Key words: Engineering Education, Structure of the Program, Industrial Links, Quality Control System.

\section{VÝUKA ENERGETIKY JE VÝZVOU PRO 21 STOLETÍ}

Resumé: Studia energetického inženýrství se znovu staly atraktivním oborem. Studenti jsou přitahováni profesními vyhlídkami, které pohání nedostatek kvalifikovaných odborníků, pracujících $\mathrm{v}$ energetickém hospodářství různých podniků. Př́íprava těchto odborníků má velké dopady na osnovu studijního programu. Studenti musí být vybaveni dovednostmi, které jim umožní, aby zůstali konkurenceschopní v daleké budoucnosti 30-40 let, v této době bude technika v energetice mít zcela jiný charakter než dnes a zároveň ještě musí být připraveni čelit výzvám dnešní doby. Tento článek se zabývá těmito otázkami a ukazuje, jak se je nový program na Univerzitě Jana Evangelisty Purkyně v Ústí nad Labem pokouší řešit. Úspěšný nárůst uchazečů a studentů v průběhu posledních tř́ let může být považován za důkaz, že program splňuje očekávání studentů a průmyslu.

Klićčóa slova: Inženýrské vzdělávání, struktura studijního programu, spojení s průmyslem, kontrola kvality vzdělávacího systému.

\section{Introduction}

In the first decade of the 21 st century, energy engineering has come back to the spotlights. Energy companies are becoming the "Most desired employers" among university students. For instance, CEZ a major Central European player with headquarters in the Czech Republic has been the most popular employer among Czech students for the last two years whilst it did not even make the top 100 in 2003 [1].

Furthermore, new century has brought many exciting challenges. Topics such as discussion of the $\mathrm{CO} 2$ emission, the liberalization of the energy market, the search for alternative fuels, renewable energy sources, or the discussion of impact of electric cars on the grid are rapidly changing the face of energy engineering. As a result, the education in energy engineering must follow.

Graduates have to be prepared for new challenges. Their technical education has to become more inter-disciplinary. The standard cocktail of mechanical and electrical engineering sufficient in the 20th century has to include new ingredients such as automation, electronics, and computer programming. Furthermore, employers expect flavors of soft skills, economics, environmental-awareness and foreign languages.

In other words, universities face a new challenge. Energy engineering graduates of the 21 st century are expected to have more practical knowledge than their predecessors. On the other hand, the theory cannot be neglected. Considering the rapid emergence of a plethora of technologies, it is almost impossible to predict what the energy engineering will look like in 20 years, not to mention in 50 years when most of current graduates will be reaching their retirement age. Only solid theoretical foundations of the engineering education can prepare the graduates to any changes their field might undergo in the future. 
Despite the increasing demands on the education, the universities cannot change the volume of the coursework. This calls for a redesign of the syllabi as the education must become more efficient. In this paper, the author discusses his experience as a lead author introducing a new course "Energy Engineering" at his university.

The paper has following structure. Firstly, the history engineering education at the Jan Evangelista Purkyne University (UJEP) is introduced and the reasons for introduction of the new undergraduate program are discussed. Then the syllabus of the course is introduced. Individual courses are linked to the goals of the program and linked to the demands mentioned in the introductions and to the situation in the marketplace. Apart from the class work, the students have a significant industrial exposure which is discussed in separate section. To ensure further development of the program, a multi-level quality control system is in place and is also introduced. Finally, the admission statistics are presented to illustrate the positive reception by the students.

\section{History of Engineering Education at UJEP}

The Jan Evangelista Purkyne University (UJEP) has been founded in 1954. Since then it has increased dramatically. Currently, it has 11,000 enrolled students and it remains the only state university in the North West of the Czech Republic. North West of the Czech Republic belongs to the most industrialized regions in the Czech Republic, with a plethora of industries including coal mining, metallurgy, power stations, chemical, automotive, food and electronics industry. Despite being in the heart of an industrialized region, the university has not taught engineering science until 1998 when it introduced the Institute of Production Technology and Management.

The institute has quickly attracted a significant number of students and academics and its expansion resulted in its transformation in a standalone Faculty of Production Technology and Management in 2006. In 2006, the faculty focused almost exclusively on Mechanical Engineering and Production Technology. In 2008, preliminary works on the new program Energy Engineering were launched and first students were admitted in 2010, following the approval of the program by the Accreditation Commission of the Czech Republic.
The main motive for the works on introduction of the new Energy Engineering program were multiple requests from industrial partners in the academic year 2008/09, who complained about the lack qualified graduates in energy engineering in the region.

The shortage of qualified engineers is a known phenomenon from across Europe, e.g. from Germany [2]. Graduates in energy engineering are especially sought after not only by major producers of electricity. In fact, every production facility needs an energy engineer who will ensure that the energy needs of the production (electricity, heat, gas, water etc.) are fully met.

In the Czech Republic, the shortage of energy engineers is even amplified. Following the social changes associated with the fall of the Iron Curtain in 1989, there was an enormous demand for graduates understanding the principles of market economy and business. The number of students in engineering was significantly reduced. As a result, a generation gap occurred in most industries. Subsequently, many companies are now recruiting new graduates to fill vacancies opened as a result of retirements. This is happening despite the global economy crisis. For instance, CEZ mentioned above plans to recruit 10,000 graduates in the course of next decade [1]. Most of these students will be placed in the North West of the Czech Republic where CEZ owns a large number of power stations.

\section{Structure of the Program}

The program has been designed according to the ECTS standards and consists of 6 terms. Each term lasts 14 weeks and is followed by a 6 week period for examinations. 12 weeks are accounted as holiday. Every term, the students are expected to conduct workload of 30 ECTS credits which correspond to 40 hours of work per week.

It is offered as full-time and part-time. The part-time program is welcomed by industry where it is used as part of their continuous education schemes for employees. Part-time students are expected to work individually over weekends and the university organizes a series of seven intensive seminars/consultations which comprise 10 lectures each.

As mentioned in the introduction, the graduates of the program should be able to be valuable employees both in the near and distant future. Therefore for the fundamental and theoretical subjects, the teaching is covered mostly by academics actively involved in 
research. Lecturers for application specific subjects are held by experts from the industry. This active involvement of industrial partners in teaching is a successful model applied at many international universities as reported e.g. in [3].

In general, the subjects taught are divided in five core groups.

The first group are the subjects of theoretical background. These include Mathematics (Calculus, Probability Theory and Statistics), Physics, Theoretical Electrical Engineering, Mechanics (Elasticity and Strength, Hydromechanics, and Thermodynamics), and Computer Programming. The main aim of these subjects is to provide sufficient theoretical fundament required by advanced classes.

In computer programming, for instance, students do not learn any specific language. Instead they should get familiar with basic programming structures such as loops, functions and threads. In our experience, if this understanding is well established, students can easily use it as a fundament for learning of a programming language required for their specific profession - this might vary from Assembler to Java. As a result, the platform chosen for the basic computer programming classes is MATLAB ${ }^{\mathrm{TM}}$.

The biggest challenge for the subjects of the fundamental subjects is the schizophrenic nature of current academia. On one hand, the entire curriculum is limited by the total of 180 ECTS for the entire degree so there is only a limited number of lectures that can be allocated for the fundamental classes. On the other hand, deep understanding of these subjects is essential for the quality of the graduates. To address this issue, we actively promote approach reported e.g. in $[5,6]$ where the theory is supported by the use of computers that help to visualize the problems like field/tension/heat distributions.

The second group of subjects, Theoretical Subjects for Energy Engineering, builds on the fundamental subjects. They aim to teach knowledge as well as the distinctive engineering thinking. In terms of knowledge students learn about materials in energy engineering, electric motors, various power station designs etc. In terms of "engineering thinking" students are taught how to apply the learned fundamental theory and engineering skills to problems they might encounter in their professional lives. For instance, in the subject Automation and control they learn how Laplace Transform is useful in control of furnace temperature.
In Application Specific Subjects the main aim is to ensure that our graduates have all the skill that will enable them to actually apply their knowledge, skills, and talents in real employment. They include: Introduction into Technical Documentation, Introduction into $\mathrm{CAD}$, Safety in Energy Engineering, Energy Engineering and the Environment etc.

In our experience students often consider these classes as non-attractive because they often do not see their importance. To increase the attractiveness of these classes we make sure that they are taught either by industrial experts or by academics with significant industrial experience or exposure. We believe that such teachers are more likely to stress the importance of these subjects. For instance, they might recall some accidents they encountered in their career in order to explain why Energy Engineering is seemingly inhibited by a plethora of rigid rules, students have to know.

The Soft Skills Classes include introductory classes into Management, or Economy. These subjects make sure that students are aware of the impact of their work on the outside world and vice versa. Often, it is important to teach students a combination of business and engineering thinking because as discussed e.g. in [2], engineering students are often keen on finding the optimum solution and the cost factor is often neglected. In real life, businesses in competitive environment look for the cheapest solution to their problems.

Finally, Language Training is a necessity for students from smaller countries such as the Czech Republic because their workplace is going to be part of the global arena. Students are expected to learn two foreign languages with the objective to achieve proficiency in their first choice language, including subject specific vocabulary. In their second choice language they are expected to achieve at least the level of a passive user with fair understanding of speech and good comprehension of written texts. The languages offered are English, German, French, Spanish, and Russian.

Additional requirement of many employers is international exposure of students. Graduates often work for global companies and are part of international teams where international experience gained during university studies enables to work more efficiently. Therefore, our faculty is actively involved in the ERASMUS program with partners in Sweden, United Kingdom, Germany, Austria or Turkey. Our aim 
is to provide every student with the opportunity to study abroad. We try to reduce the administrative burden associated with transfer of credits to a necessary minimum and we try to ensure that the number of places offered by the ERASMUS program is at least equal to the number of students interested in such opportunity. Since the establishment of the Institute of Production Technology and Management in 1998, every student willing to spend a term or two abroad has been offered a place.

\section{Industrial Links}

As mentioned in the preceding sections, we are constantly fostering our relationship to the industry and try to link our students with potential employers. We require every student to take up an industrial internship lasting at least 4 weeks. These internships are organized during summer holiday periods. During the industrial internship, students work on projects prepared by the industrial partner. At the end of the internship they present their result in front of a committee with representatives from academia and industry.

Furthermore, in the final projects students either work jointly with the academics on one of the current research themes or most of the projects are specified jointly with industrial partners and students have two supervisors. The academic supervisors overlook the academic and theoretical quality of the project whereas the industrial partners focus on the relevance for their business.

This policy has received a positive feedback from both students and employers. Students gain their first professional experience which is useful in future job applications whereas employers have the opportunity for thorough assessment of the students. In most cases, students are immediately offered a permanent position which is a win-win situation. Employers save costs for training and students can use their placement as a trial evaluation period whether the specific corporate culture meets their expectations.

\section{Quality Control System}

An undergraduate program is an evolving organism and improvements of the programs are happening on daily basis. For instance, academics are encouraged to include their latest research into the teaching. To support this process, our program has a multilevel system for feedback and control, which has been successfully employed in other programs of the faculty.
Students are invited to express their comments to the program and individual classes in anonymous surveys at the end of each term. Further control is facilitated by inspections in classes where senior academics evaluate the teaching of their colleagues. This is organized at two levels - at the faculty level and at the university level.

The final projects of students are evaluated in terms of quality as well as in terms of topic choice similarly as in a survey presented in [6].

Finally, the faculty has a scientific council and an industrial council. The scientific council is a standard body for every academic institution in the Czech Republic. It consists of senior academics mostly from other institutions. Its task is to supervise and guarantee the scientific and academic quality of the research conducted and degrees awarded at the institution. This body has the right to demand changes in the program that are deemed necessary.

On top of that, our faculty has voluntarily introduced an industrial council. It is a body of industry representatives who often do not hold sufficient academic qualification to be part of the scientific councils but have influential managerial posts in their companies. Similarly to the scientific council, the industrial council has the right to express on the quality and organization of our teaching programs. Unlike the scientific council, they do not have a lawful right to demand the changes but since they represent future employers of our graduates, their suggestions are carefully considered and implemented. In fact, it was the scientific council that suggested that a new program in Energy Engineering should be introduced to meet the current and projected shortage of skilled professionals in the field.

\section{Admission Statistics}

The program has been introduced in 2010 . At the moment, we have received applications for third year of the program. The numbers for parttime and full-time program are presented in Fig. 1. For the year 2010/11, administrative delays in the accreditation process did not allow us to announce the program before the national deadline for application for high school finalists, where we recruit virtually all of our full-time students. As a result, in 2010/11, Energy Engineering was only offered as part-time program for mature students already in employment. 
As can be seen, the interest in the program has been steadily increasing which is evidence that the program is attractive for students. Moreover, the increase in the applications for the part-time program is seen as evidence that the program is well valued by the industry.
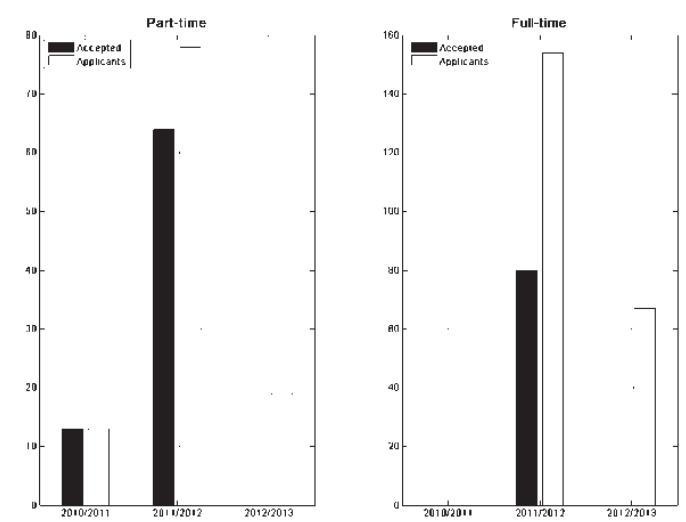

*) Year 2012/2013 - only to May 31st

\section{Conclusions}

In this paper, we introduced the new program Energy Engineering that has recently been launched by the Jan Evangelista Purkyne University in Usti nad Labem, Czech Republic. The program has been launched following a request from industry as our industrial partners have a serious shortage of professionals in energy engineering.

In the paper, we introduce the structure of the program but we also link specific subjects to skills that are required by the employers today and that will be required in distant future as we are aware that the retirement of many of our graduates will be past 2050 .

Considering the rapid development in the areas such as electric vehicles, smart grids, or renewable energy resources, most of current academics are, despite working on these topics, hardly in the position to foresee and understand the requirements that the future will bring. This stresses the need for quality fundamental education in the engineering approach to problem solving.

The author hopes that this paper will enable him to provide inspiration and to share his experience with creating a new program with colleagues who will be opening similar programs or will be re-designing their current curricula in energy engineering in order to address the rapidly changing environment of energy engineering.

\section{Literatura}

[1] NOVOTNÝ P.P. Šéf ČEZ Roman: Absolventy bereme i za 25 tisíc, dobrým rychle přidáme // MF Dnes - MF Dnes, 2011, 13 July 2011

[2] MULLER B. Engineers Made in Germany // DAAD Letter, 2010, No. 3, Vol. 30 - P. 9 - 12

Doc. Ing Jaroslav Šípal, PhD.

Katedra energetiky a elektrotechniky

Fakulta výrobních technologií a managementu UJEP Ústí nad Labem

Na Okraji 1001; 40096 Ústí nad Labem; ČR

Tel: +420 475285515

E-mail: sipal@fvtm.ujep.cz

Www pracoviště: www.fvtm.ujep.cz 